\title{
Physiognomy and structure of a caatinga with Cordia oncocalyx (Boraginaceae), a new type of community in Andrade-Lima's classification of caatingas
}

\author{
Fisionomia e estrutura de uma caatinga com Cordia oncocalix (Boraginaceae), \\ um novo tipo de comunidade na classificação das caatingas de Andrade-Lima
}

\author{
Rafael Carvalho da Costa $^{1,2,3}$ \& Francisca Soares de Araújo ${ }^{2}$
}

\begin{abstract}
Recently, the inclusion of physiognomies with Cordia oncocalyx Allemão (Boraginaceae) as a new type/ unit within Andrade-Lima's classification of caatingas (ALFPC) has been proposed. However, no study has quantitatively analyzed this proposal so far. In order to fill this gap, a phytosociological study was conducted in a caatinga with $C$. oncocalyx, and differences in structure and physiognomy in relation to compiled caatinga studies were verified. 1795 plants from 25 species and a total basal area of $35.26 \mathrm{~m}^{2}$ were found. C. oncocalyx and Mimosa caesalpiniifolia Benth. (Fabaceae) had $48 \%$ of total importance index (IV). The physiognomy was characterized by the predominance of individuals of intermediate height (3-4 $\mathrm{m})$ and the tallest ones accounted for the highest fraction of basal area. Of the five species with highest IV, only one had high frequency among the species with highest IV in the compiled studies (16/35). Only two of these compiled studies were comparable to the present study, and only one could be classified according to ALFPC. A contrast between that study and the present one was found, as the first reports a dense community with high number of small diameter individuals accounting for most of the basal area. These findings suggest the suitability of including $C$. oncocalyx caatingas in low and medium caatinga forests as proposed in ALFPC. However, the low number of comparable studies limits generalizations.
\end{abstract}

Key-words: community structure, phytosociology, semi-arid, vegetation classification.

\section{Resumo}

Recentemente foi proposta a inclusão de fisionomias com Cordia oncocalyx Allemão (Boraginaceae) como um novo tipo/unidade à classificação de caatingas de Andrade-Lima (CFFAL). Porém, nenhum estudo avaliou quantitativamente essa proposta. Este estudo visou descrever a fisionomia e estrutura de uma caatinga com C. oncocalyx comparando-a a outros estudos para verificar diferenças estruturais e fisionômicas. Amostrou-se 1795 indivíduos de 25 espécies, somando uma área basal de 35,26 $\mathrm{m}^{2}$. C. oncocalyx e Mimosa caesalpiniifolia Benth. (Fabaceae) representaram 48\% do VI total. A fisionomia foi caracterizada pelo predomínio de indivíduos de altura intermediária $(3-4 \mathrm{~m})$ e concentração de área basal nos indivíduos altos (>8 m). Dentre as cinco espécies com maior valor de importância (VI), apenas uma teve frequência alta dentre as cinco espécies de maior VI de levantamentos compilados (16/35). Desses levantamentos, apenas dois eram comparáveis a este estudo e só um pôde ser classificado conforme a CFFAL, inserindo-se dentre caatingas arbóreas abertas. Nesse caso, a comunidade era densa e dominada por indivíduos finos e baixos, em contraste à caatinga aqui estudada. Os resultados indicam a adequação da inclusão das caatingas com C. oncocalyx dentre caatingas florestais médias e baixas da CFFAL. Porém, o baixo número de estudos comparáveis limita o alcance de generalizações.

Palavras-chave: classificação de vegetação, estrutura de comunidades, fitossociologia, semiárido.

\footnotetext{
' Programa de Pesquisas de Longa Duração (PELD/CNPq) Site Caatinga: structure and functioning.

${ }^{2}$ Universidade Federal do Ceará, Campus do Pici, Centro de Ciências, Depto. Biologia, B1. 906, 60455-760, Fortaleza, CE, Brazil.

${ }^{3}$ Corresponding author: carvalhorafael@yahoo.com
} 


\section{Introduction}

The dominant plant formation in Brazilian semi-arid region, known as caatinga, is frequently mentioned in the literature as widely variable in composition as well as in physiognomy, in response to the heterogeneity of climate, topography, types of soil and anthropic influnce (Andrade-Lima 1981; Sampaio 1995; Fernandes 1998). Such heterogeneity has motivated many proposals for classification of types of caatinga, based on physiognomic as well as on floristic-physiognomic criteria (Luetzelburg 1923; Rizzini 1979; AndradeLima 1981; Eiten 1983; Fernandes 1998; Veloso et al. 1991).

Amongst the existing systems, the floristicphysiognomic classification by Andrade-Lima (1981 - hereafter referred to as ALFPC) is regarded as one of the most important ones due to the details it presents (Sampaio 1995). AndradeLima (1981) divided the caatingas into 12 main vegetation types, based on what he considered to be the most "remarkable" species, and grouped them into six physiognomic units. These units include tall caatinga forests (unit I), median and low caatinga forests (units II and III), shrubby caatingas (units IV and V), and fringe caatinga forests (unit VI).

Although Andrade-Lima (1981) had emphasized the provisionality of his classification, it was only 12 years later that Prado (2003) proposed the inclusion of a new type of community. This new type was mentioned by Andrade-Lima (1981) as a facie within II, median and low caatinga forests, characterized by a group of major species which are uncommon to other vegetation types described, especially Auxemma oncocalyx Baill. (currently repositioned to Cordia (Boraginaceae) Gottschling \& Miller 2006).

As well as Andrade-Lima (1981), Prado's proposal (2003) was also based on qualitative observations, and so far there are no quantitative descriptions explicitly dealing with the types of caatinga communities proposed in ALFPC, limiting the quantitative evaluation of scope and applicability of ALFPC, as well as of the inclusion of the new community proposed by Prado (2003). Aiming to fill that gap, the objective of this study was to describe the physiognomy and structure of a caatinga community with Cordia oncocalyx Allemão, and compare it to other studies in caatinga communities in order to find out if it is characterized by a unique group of major species and how much it differs from the others phytosociologically.

\section{Material and Methods}

The survey was carried out at RPPN Serra das Almas (5 $7^{\circ} 0.01^{\prime \prime} \mathrm{S}$ and $40^{\circ} 52^{\prime} 22.79^{\prime \prime} \mathrm{W}$ ), municipality of Crateús, Central-western region of the state of Ceará. The reserve was created in 2000 (IBAMA Normative Act no. 51/00 of 08/09/00), and covers an area of 6,146 hectares, comprising slopes and the top of the Ibiapaba plateau and of the adjacent depression on the crystalline basement complex. $29.19 \%$ from the total area of the reserve corresponds to caatinga vegetation. Data collection was carried out in an area on crystalline depression at Grajau, at an altitude of $368 \mathrm{~m}$, on Planosol. Average annual rainfall in this area is $698 \mathrm{~mm}$, $84 \%$ concentrated from January to April (rainy season). In September and October, on average, rainfall accounts for less than $1 \mathrm{~mm}$, and the average annual temperature is $26.8^{\circ} \mathrm{C}$ (Ibiapaba meteorological station, $8 \mathrm{~km}$ from the study site, 20-year time series, according to Fundação Cearense de Meteorologia data). The area has been protected since 1998, and in previous excursions, little evidence of selective logging was observed in the study site, as well as high occurrence of $C$. oncocalyx, species that defines the new type of community proposed by Prado (2003).

In this area, a phytosociological survey was carried out in January 2003, in a permanent plot (reference coordinates: $40^{\circ} 52^{\prime} 21^{\prime \prime} \mathrm{S}, 5^{\circ} 6{ }^{\prime} 59^{\prime \prime} \mathrm{W}$ ) subdivided in 100 sub-plots of $10 \times 10 \mathrm{~m}$. The height was estimated and diameter was measured for plants with up to $3 \mathrm{~cm}$ of diameter at ground level (DNS). Each individual was marked with a metal tag and previously identified in the field; this identification was later verified by the collection of reproductive botanical material and consultation of botanical identification keys and herbarium material. The botanical material was deposited in the EAC herbarium. The delimitation of families followed the APG III system (2009).

The collected data was tabulated on a spreadsheet (BrOfice.org 3.0.1, Sun Microsystems, Inc.), and the general phytosociological parameters were calculated: density, total basal area, mean and maximum height and diameter, richness and Shannon's diversity index (H', in natural logarithm). Frequency distributions were constructed for individuals and for the sum of the basal area by 
height classes and of frequencies of individuals by diameter claasses. To make the comparisons easier, the same classes used in other studies were adopted (Alcoforado-Filho et al. 2003; Rodal et al. 2008b). Whenever possible, the Kolmogorov-Smirnov test was carried out in order to test differences among size distributions.

Articles and thesis containing phytosociological surveys carried out in caatinga vegetation areas were compiled for comparisons among general phytosociological parameters. (Tab. 1). Each area studied in the selected surveys was considered as a separate survey and classified according to ALFPC, based on genera with highest importance value and on geographical location.

For each species included in our survey, the frequency, density, and absolute and relative dominance, as well as the Importance Value (IV) were calculated. The phytosociological calculations were made with the aid of the software Fitopac 1.0 (Shepherd 1995), and the charts and statistics in $\mathrm{R}$ environment, version 2.10.0 (R Development Core Team 2009).

In order to verify whether the most important species of a caatinga with $C$. oncocalyx are uncommon in other types of caatinga communities, we counted the number of times each of the highest IV species in this study occured among highest IV species of the compiled studies (Tab. 1). In these comparisons, only surveys that used an inclusion criterion similar to this study were used.

\section{Results and Discussion}

The studied caatinga had a richness of 14 families and 25 species, specific Shannon diversity of 2.271. Fabaceae was the family with the highest richness, with more than a third of the species, followed by Euphorbiaceae and Apocynaceae, with three and two species, respectively (Tab. 2 ). The community was characterized by the high phytosociological importance of few species: Cordia oncocalyx Allemão and Mimosa caesalpiniifolia Benth. correspond to almost half the sum of IV for all sampled species (Tab. 2). The high importance of these species in the community is due to different characteristics; C. oncocalyx concentrates more than $50 \%$ of all the basal area of the sample, has plants with large diameters, frequency and intermediate densities (Tab. 2). M. caesalpiniifolia, on the other hand, has high IV associated with high density and frequency of individuals in the sample (Tab. 2).
Phytosociological surveys of 35 caatinga areas were compiled (Tab. 1). The comparison of the five species with highest IV in the studied caatinga with the caatingas in the other surveys shows that the former is characterized by an uncommon group of major species (Tab. 3). Only Croton blanchetianus Müll. Arg. (identified in the other surveys as Croton sonderianus Müll. Arg.) has significant occurrence (16 out of 35 surveys) among the five most important species in the compared surveys. The second species with greater IV in this study, Poincianella bracteosa (Tul.) L.P.Queiroz, occurred in only 2 out of 35 surveys cited. In the context of ALFPC, this result shows that, as Andrade-Lima (1981) and Prado (2003) had proposed, from the floristic point of view, the caatingas with $C$. oncocalyx can be considered a distinguished type of community within this classification, as they actually present a unique group of major species.

1,795 individuals. ha ${ }^{-1}$ were registered, which corresponds to a total basal area of $35.26 \mathrm{~m}^{2}$. This group had median height of $4.64 \mathrm{~m}$ (standard deviation $=1.8 \mathrm{~m}$ ) and maximun height of $13 \mathrm{~m}$, while the mean and maximum diameters were $11.3 \mathrm{~cm}$ (standard deviation $=11 \mathrm{~cm}$ ) and $85.9 \mathrm{~cm}$, respectively. The community was characterized by numerical predominance of individuals 2 to $5 \mathrm{~m}$ tall (66\%, Fig. 1a) and by high concentration of basal area in individuals taller than $6 \mathrm{~m}(65 \%$, Fig. 1b).
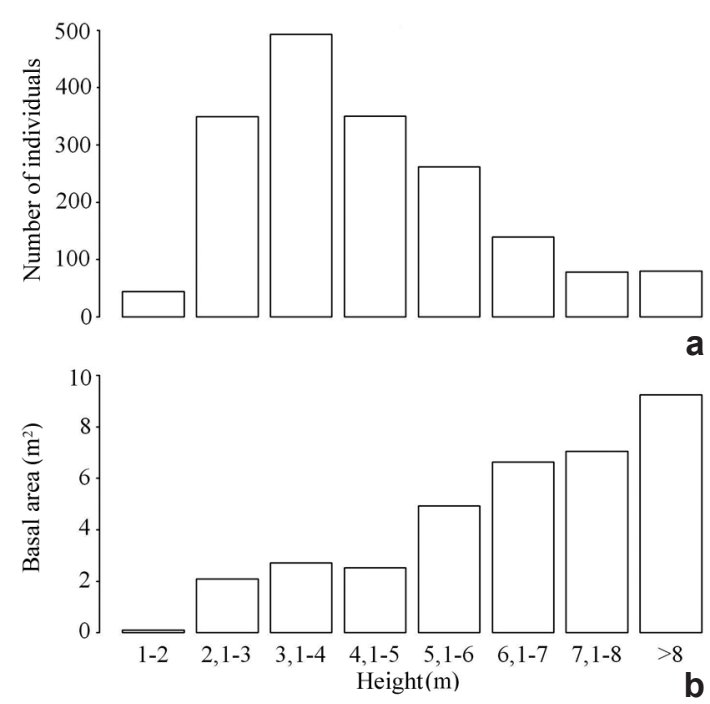

Figure 1 - Frequency distributions of the number of individuals (a) and total basal area (b) by height class in the studied plot at RPPN Serra das Almas, Crateús, Ceará. 
Table 1 - Compiled phytosociological studies with respective location, sample effort (in hectares), sample method (MET), inclusion criteria (CI) and common species among the five highest IV species in this study and the five highest IV species in each compiled study. $\mathrm{P}$ - plot method, DNS $>=3$ - diameter at soil level equal to or greater than $3 \mathrm{~cm}, \mathrm{CAB}>=10$ - perimeter at soil level equal to or greater than $10 \mathrm{~cm}, \mathrm{CAB}>=12$ - perimeter at soil level equal to or greater than $12 \mathrm{~cm}$.

\begin{tabular}{|c|c|c|c|c|c|c|c|}
\hline Reference & Municipality & Location & State & Effort & MET & CI & $\begin{array}{l}\text { Coincident species } \\
\text { with highest IV }\end{array}$ \\
\hline $\begin{array}{l}\text { Alcoforado-Filho et al. } \\
(2003)\end{array}$ & Caruarú & IPA & $\mathrm{PE}$ & 7200 & $\mathrm{P}$ & $\mathrm{DNS}>=3$ & - \\
\hline Andrade et al. (2005) & São João do Carirí & E.E. UFPB 2 & $\mathrm{~PB}$ & 2400 & $P$ & $\mathrm{CAB}>=10$ & Croton sonderianus \\
\hline Andrade et al. (2005) & São João do Carirí & E.E. UFPB 1 & PB & 2400 & $\mathrm{P}$ & $\mathrm{CAB}>=10$ & Croton sonderianus \\
\hline Barbosa et al. (2007) & $\begin{array}{l}\text { São José dos } \\
\text { Cordeiros }\end{array}$ & RPPN Faz. Almas & PB & 5000 & $\mathrm{P}$ & $\mathrm{DNS}>=3$ & Croton sonderianus \\
\hline Barbosa et al. (2007) & São joão do Carirí & E.E. de S.J. do Carirí & PB & 1080 & $\mathrm{P}$ & $\mathrm{DNS}>=3$ & Croton sonderianus \\
\hline $\begin{array}{l}\text { Fabricante \& Andrade } \\
(2007)\end{array}$ & Santa Luzia & Faz. Madalena & $\mathrm{PB}$ & 4000 & $\mathrm{P}$ & $\mathrm{DNS}>=3$ & Croton sonderianus \\
\hline Ferraz et al. (2003) & Serra Talhada & Pimenteira & $\mathrm{PE}$ & 2000 & $\mathrm{P}$ & $\mathrm{DNS}>=3$ & Croton sonderianus \\
\hline Ferraz et al. (2003) & Serra Talhada & Mandassaia & $\mathrm{PE}$ & 1000 & $\mathrm{P}$ & $\mathrm{DNS}>=3$ & Croton sonderianus \\
\hline Fonseca (1991) & $\begin{array}{l}\text { Canindé do São } \\
\text { Francisco }\end{array}$ & Faz. California & SE & 1500 & $\mathrm{P}$ & $\mathrm{DNS}>=3$ & - \\
\hline Fonseca (1991) & $\begin{array}{l}\text { Canindé do São } \\
\text { Francisco }\end{array}$ & Curituba & $\mathrm{SE}$ & 1500 & $\mathrm{P}$ & $\mathrm{DNS}>=3$ & - \\
\hline Fonseca (1991) & Poço Redondo & Faz. Barra (B) & SE & 1500 & $\mathrm{P}$ & $\mathrm{DNS}>=3$ & - \\
\hline Fonseca (1991) & $\begin{array}{l}\text { Canindé do São } \\
\text { Francisco }\end{array}$ & Estr. Brejo & SE & 1500 & $\mathrm{P}$ & $\mathrm{DNS}>=3$ & - \\
\hline Fonseca (1991) & Poço Redondo & $\begin{array}{l}\text { Faz. Barra da Onça } \\
\text { (A) }\end{array}$ & SE & 1500 & $\mathrm{P}$ & $\mathrm{DNS}>=3$ & - \\
\hline Freitas et al. (2007) & Messias Targino & Faz. Soares 2 & $\mathrm{RN}$ & 2400 & $\mathrm{P}$ & $\mathrm{DNS}>=3$ & Croton sonderianus \\
\hline Freitas et al. (2007) & Messias Targino & Faz. Soares 1 & $\mathrm{RN}$ & 2400 & $\mathrm{P}$ & $\mathrm{DNS}>=3$ & Croton sonderianus \\
\hline Lemos \& Rodal (2002) & $\begin{array}{l}\text { São Raimundo } \\
\text { Nonato }\end{array}$ & $\begin{array}{l}\text { PARNA Serra da } \\
\text { Capivara }\end{array}$ & PI & 10000 & $\mathrm{P}$ & $\mathrm{DNS}>=3$ & - \\
\hline Maracajá et al. (2003) & Serra do Mel & V1. Sta. Catarina 1 & $\mathrm{RN}$ & 2400 & $\mathrm{P}$ & $\mathrm{CAB}>=10$ & Croton sonderianus \\
\hline Maracajá et al. (2003) & Serra do Mel & V1. Sta. Catarina 2 & $\mathrm{RN}$ & 2400 & $\mathrm{P}$ & $\mathrm{CAB}>=10$ & Croton sonderianus \\
\hline Moreira et al. (2007) & Caraúbas & $\begin{array}{l}\text { Xique-xique } \\
\text { (Preservada) }\end{array}$ & $\mathrm{RN}$ & 2400 & $\mathrm{P}$ & $\mathrm{CAB}>=12$ & $\begin{array}{l}\text { Poincianella } \\
\text { bracteosa }\end{array}$ \\
\hline Moreira et al. (2007) & Caraúbas & $\begin{array}{l}\text { Xique-xique } \\
\text { (Antropizada) }\end{array}$ & $\mathrm{RN}$ & 2400 & $\mathrm{P}$ & $\mathrm{CAB}>=12$ & $\begin{array}{l}\text { Croton sonderianus, } \\
\text { Poincianella } \\
\text { bracteosa }\end{array}$ \\
\hline $\begin{array}{l}\text { Nascimento et al. } \\
(2003)\end{array}$ & PetrolinaD+TL & EMBRAPA (D+TL) & PE & 4300 & $\mathrm{P}$ & $\mathrm{DNS}>=3$ & - \\
\hline $\begin{array}{l}\text { Nascimento et al. } \\
\text { (2003) }\end{array}$ & PetrolinaDI+TL & EMBRAPA (DI+TL) & $\mathrm{PE}$ & 7900 & $\mathrm{P}$ & $\mathrm{DNS}>=3$ & - \\
\hline $\begin{array}{l}\text { Nascimento et al. } \\
(2003)\end{array}$ & PetrolinaMR & EMBRAPA (MR) & PE & 400 & $\mathrm{P}$ & $\mathrm{DNS}>=3$ & - \\
\hline
\end{tabular}




\begin{tabular}{|c|c|c|c|c|c|c|c|}
\hline Reference & Municipality & Location & State & Effort & MET & CI & $\begin{array}{l}\text { Coincident species } \\
\text { with highest IV }\end{array}$ \\
\hline $\begin{array}{l}\text { Nascimento et al. } \\
\text { (2003) }\end{array}$ & PetrolinaTS & EMBRAPA (TS) & $\mathrm{PE}$ & 400 & $\mathrm{P}$ & $\mathrm{DNS}>=3$ & Croton sonderianus \\
\hline Pegado et al. (2006) & Monteiro & Ambiente 2 & PB & 4000 & $\mathrm{P}$ & DNS $>=3$ & - \\
\hline Pegado et al. (2006) & Monteiro & Ambiente 1 & $\mathrm{~PB}$ & 4000 & $\mathrm{P}$ & $\mathrm{DNS}>=3$ & - \\
\hline Pereira et al. (2002) & Areia/ Remígio & Faz. São Bento & PB & 6000 & $\mathrm{P}$ & $\mathrm{DNS}>=3$ & Croton sonderianus \\
\hline Queiroz et al. (2006) & Boqueirão & Sa. do Monte & PB & 2000 & $\mathrm{P}$ & DNS $>=3$ & Croton sonderianus \\
\hline Rodal et al. (2008a) & Custódia & Boa Vista (direita) & $\mathrm{PE}$ & 2500 & $\mathrm{P}$ & $\mathrm{DNS}>=3$ & - \\
\hline Rodal et al. (2008a) & Custódia & Boa Vista (esquerda) & $\mathrm{PE}$ & 2500 & $\mathrm{P}$ & $\mathrm{DNS}>=3$ & - \\
\hline Rodal et al. (2008a) & Floresta & Fasa & $\mathrm{PE}$ & 2500 & $\mathrm{P}$ & $\mathrm{DNS}>=3$ & - \\
\hline Rodal et al. (2008a) & Floresta & Poço do Ferro & $\mathrm{PE}$ & 2500 & $\mathrm{P}$ & $\mathrm{DNS}>=3$ & - \\
\hline Rodal et al. (2008b) & Floresta/ Betânia & $\begin{array}{l}\text { RPPN Maurício } \\
\text { Dantas }\end{array}$ & $\mathrm{PE}$ & 10000 & $\mathrm{P}$ & $\mathrm{DNS}>=3$ & - \\
\hline $\begin{array}{l}\text { Santana \& Souto } \\
\text { (2006) }\end{array}$ & Serra Negra do Norte & ESEC Seridó & $\mathrm{RN}$ & 6000 & $\mathrm{P}$ & DNS $>=3$ & Croton sonderianus \\
\hline Santos et al. (2007) & Montes Claros & Pq. Mun. da Sapucaia & MG & 4000 & $\mathrm{P}$ & $\mathrm{CAB}>=10$ & - \\
\hline
\end{tabular}

Table 2 - Phytosociological parameters of sampled species in the studied plot at RPPN Serra das Almas, Crateús, Ceará. $\mathrm{N}^{\circ}$ ind - number of individuals, $\mathrm{Fr}$ - absolute frequency, $\mathrm{AB}$ - basal area in $\mathrm{m}^{2}$, IV - importance value, $\%$ IV - percentage of total IV of all species.

\begin{tabular}{|c|c|c|c|c|c|c|c|}
\hline Species & Voucher & Family & $\mathbf{N}^{\circ}$ ind & Fr & $\mathbf{A B}$ & IV & $\%$ IV \\
\hline Cordia oncocalyx Allemão & R.C. Costa, 404 & Boraginaceae & 195 & 59 & 18,301 & 73,13 & 24,38 \\
\hline Mimosa caesalpiniifolia Benth. & R.C. Costa, 399 & Fabaceae & 530 & 95 & 8,554 & 70,48 & 23,49 \\
\hline Croton adenocalyx Baill. & F.S. Araújo, 1346 & Euphorbiaceae & 250 & 45 & 2,750 & 29,63 & 9,88 \\
\hline Croton blanchetianus Müll. Arg. & F.S. Araújo, 1356 & Euphorbiaceae & 255 & 54 & 0,434 & 24,93 & 8,31 \\
\hline Poincianella bracteosa (Tul.) L.P.Queiroz & R.C. Costa, 401 & Fabaceae & 75 & 50 & 2,419 & 19,83 & 6,61 \\
\hline Bauhinia cheilantha (Bong.) Steud. & F.S. Araújo, 1397 & Fabaceae & 124 & 51 & 0,352 & 16,87 & 5,62 \\
\hline Piptadenia stipulacea (Benth.) Ducke & F.S. Araújo, 1426 & Fabaceae & 94 & 45 & 0,350 & 14,14 & 4,71 \\
\hline Combretum leprosum Mart. & F.S. Araújo, 1516 & Combretaceae & 45 & 33 & 0,167 & 8,78 & 2,93 \\
\hline Cochlospermum vitifolium (Willd.) Spreng. & S.F. Vasconcelos, 4 & Bixaceae & 61 & 13 & 0,232 & 6,34 & 2,11 \\
\hline Myracrodruon urundeuva Allemão & PROBIO, 400 & Anacardiaceae & 25 & 18 & 0,624 & 6,33 & 2,11 \\
\hline Aspidosperma pyrifolium Mart. & PROBIO, 403 & Apocynaceae & 22 & 16 & 0,306 & 4,91 & 1,64 \\
\hline Justicia sp. & F.S. Araújo, 1539 & Acanthaceae & 27 & 13 & 0,238 & 4,46 & 1,49 \\
\hline $\begin{array}{l}\text { Pseudobombax marginatum (A. St.-Hil., Juss. \& } \\
\text { Cambess.) A. Robyns }\end{array}$ & F.S. Araújo, 1553 & Malvaceae & 21 & 16 & 0,124 & 4,33 & 1,44 \\
\hline
\end{tabular}




\begin{tabular}{|c|c|c|c|c|c|c|c|}
\hline Species & Voucher & Family & $N^{\circ}$ ind & Fr & $\mathbf{A B}$ & IV & $\%$ IV \\
\hline $\begin{array}{l}\text { Anadenanthera colubrina var. cebil (Griseb.) } \\
\text { Reis }\end{array}$ & R.C. Costa, 562 & Fabaceae & 18 & 14 & 0,173 & 3,96 & 1,32 \\
\hline Amburana cearensis (Allemão) A. C. Sm. & M.S. Sobrinho, 202 & Fabaceae & 12 & 10 & 0,064 & 2,61 & 0,87 \\
\hline Mimosa tenuiflora (Willd.) Poir. & F.S. Araújo, 1544 & Fabaceae & 12 & 9 & 0,029 & 2,33 & 0,78 \\
\hline Libidibia ferrea (Mart. ex Tul.) L.P.Queiroz & F.S. Araújo, 1555 & Fabaceae & 9 & 9 & 0,052 & 2,23 & 0,74 \\
\hline Jatropha mollissima (Pohl) Baill. & R.C. Costa, 350 & Euphorbiaceae & 6 & 5 & 0,012 & 1,25 & 0,42 \\
\hline $\begin{array}{l}\text { Aspidosperma cuspa (Kunth) S. F. Blake ex } \\
\text { Pittier }\end{array}$ & F.S. Araújo, 1352 & Apocynaceae & 4 & 4 & 0,008 & 0,95 & 0,32 \\
\hline Lantana camara $\mathrm{L}$. & R.C. Costa, 370 & Verbenaceae & 4 & 4 & 0,005 & 0,94 & 0,31 \\
\hline Guapira graciliflora (Schmidt) Lundell & J.R. Lima, 34 & Nyctaginaceae & 2 & 2 & 0,006 & 0,48 & 0,16 \\
\hline Commiphora leptophloeos (Mart.) J.B. Gillett & J.R. Lima, 48 & Burseraceae & 1 & 1 & 0,050 & 0,37 & 0,12 \\
\hline Erythrina velutina Willd. & R.C. Costa, 328 & Fabaceae & 1 & 1 & 0,009 & 0,26 & 0,09 \\
\hline Cynophalla flexuosa (L.) J. Presl. & Observada & Capparaceae & 1 & 1 & 0,003 & 0,24 & 0,08 \\
\hline Handroanthus impetiginosus Mattos. & Observada & Bignoniaceae & 1 & 1 & 0,001 & 0,23 & 0,08 \\
\hline
\end{tabular}

Table 3 - Frequency of the five species with highest IV in this study among five species with highest IV among 35 compiled caatinga phytosociological studies. Compiled studies were from Brazilian northeastern states and Minas Gerais state and are listed in Table 1.

\begin{tabular}{llccc}
\hline Species & Family & \%IV & IV & Frequency \\
\hline Cordia oncocalyx & Boraginaceae & 24,38 & 73,13 & 0 \\
Mimosa caesalpiniifolia & Fabaceae & 23,49 & 70,48 & 0 \\
Croton adenocalix & Euphorbiaceae & 9,88 & 29,63 & 0 \\
Croton blanchetianus & Euphorbiaceae & 8,31 & 24,93 & $16 / 35$ \\
Poincianella bracteosa & Fabaceae & 6,61 & 19,83 & $2 / 35$ \\
\hline
\end{tabular}

Of the 35 compiled surveys (Tab. 1), only two present method, inclusion criterion and sampling efforts similar to those in the present study (Rodal et al. 2008b, Lemos \& Rodal 2002). Based on the genera of the major species and on geographic location, it was only possible to classify the survey by Rodal et al. (2008b) according to ALFPC. The caatinga described in the study by Lemos \& Rodal (2002) does not fit the types of community in ALFPC, which indicates the possibility of new proposals to include types of communities in Andrade-Lima's classification (1981).

The caatinga studied by Rodal et al. (2008b) was classified in unit II, type six, which corresponds to "caatingas arbóreas abertas" (open arboreous caatingas). When compared to the caatinga with $C$. oncocalyx studied here, remarkable physiognomic differences are observed (the same classes were used for the size distributions). In relation to that survey, the caatinga studied here has low density $(1,795$ $\times 3,140$ individuals $\mathrm{ha}^{-1}$ ) and high basal area $\left(35.26 \times 18.5 \mathrm{~m}^{2} \mathrm{ha}^{-1}\right)$. High density in Rodal et al. (2008b) is due to short individuals (the modal height is 1 to $2 \mathrm{~m}$ ) that concentrate most of the sampled basal area (figure 2 in Rodal et al. 2008b). Here, there is a predominance of individuals of intermediate height (modal height 3 to $4 \mathrm{~m}$ ); however, the largest concentration of basal area corresponds to large individuals, 


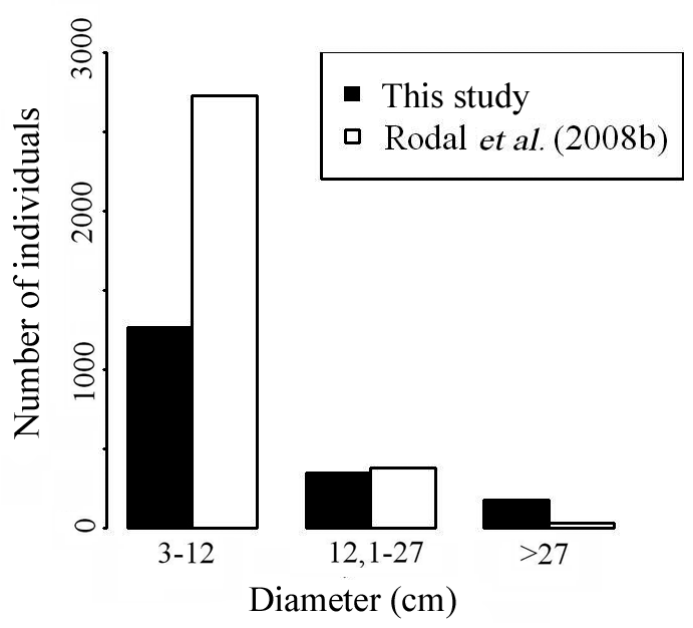

Figure 2 - Frequency distributions of individuals in diameter classes in the studied plot at RPPN Serra das Almas, Crateús, Ceará; and in Rodal et al. (2008).

especially of the species $C$. oncocalyx, which reaches $70 \%\left(16.1 \mathrm{~m}^{2}\right)$ of the basal area of individuals taller than $6 \mathrm{~m}$. Although the distribution of individuals into three diameter classes had not differed (Kolmogrov-Smirnov, D $=0.33, \mathrm{p}=1)$, a comparison of the absolute values shows that, in Rodal et al. (2008b) there are more individuals in the smaller diameter class, while in this study there is greater density of individuals in the larger diameter class (Fig. 2).

Although the caatinga studied by Rodal et al. (2008b) has been classified as type six (open arboreous caatingas - low density), its characteristics do not agree exactly with the physiognomic definition of this type of community, since it had high plant density. However, the characteristics of greater heights of the plants and low density placed the caatinga studied here in Andrade-Lima's description (1981) for the types of caatinga in unit II (median and low caatinga forests and open arboreous caatingas). The high concentration of basal area in larger individuals seems to be a unique characteristic of the studied caatinga, especially because this characteristic is due, in large part, to a single species, C. oncocalyx. This point should be better explored in posterior comparative studies aiming to define more precisely whether this is an exclusive aspect and what is the ecological importance of $C$. oncocalyx in the structuring of this type of community.
The results and comparisons obtained in this study show that, physiognomically, the new type of community proposed in ALFPC corresponds to the median and low caatinga forests of unit II, while the presence of a unique group of major species distinguishes it from the other community types in ALFPC. It should be noted that the limited number of surveys available for comparison in the literature limits a more consistent quantitative assessment of the physiognomic variation among other types of caatinga and this one, and only generalizations of primary nature are possible.

\section{Acknowledgments}

The authors thank Conselho Nacional de Desenvolvimento Científico e Tecnológico $(\mathrm{CNPq})$ for the financial support for the execution of field activities (through the project Estrutura e Funcionamento de Formações Xerófilas no Estado do Ceará - Edital Universal), for the AT-NS student stipend granted to the first author by Programa de Pesquisas de Longa Duração (PELD/CNPq) Site Caatinga: estrutura e funcionamento (Subproject: Estrutura e Dinâmica da Vegetação na Caatinga do Nordeste do Brasil), by the "productivity in research" grant to the second author; the managers of Associação Caatinga and RPPN Serra das Almas for the permission and logistical support for data collection; Jacira Rabelo Lima, Luciana Coe Girão and Sandra Freitas de Vasconcelos for helping in the field activities.

\section{References}

Alcoforado-Filho, F.G.; Sampaio, E.V.S.B. \& Rodal, M.J.N. 2003. Florística e fitossociologia de um remanescente de vegetação caducifólia espinhosa arbórea em Caruaru, Pernambuco. Acta Botanica Brasilica 17: 289-305.

Andrade-Lima, D. 1981. The caatingas dominium. Revista Brasileira de Botânica 4: 149-153.

Andrade, L.A.; Pereira, I.M.; Leite, U.T. \& Barbosa, M.R.V. 2005. Análise da cobertura de duas fitofisionomias de caatinga, com diferentes históricos de uso, no município de São João do Cariri, Estado da Paraíba. Cerne 11: 263-282.

APG III. 2009. An update of the Angiosperm Phylogeny Group classification for the orders and families of flowering plants: APG III. Botanical Journal of the Linnean Society 161: 105-121.

Barbosa, M.R.V.; Lima, I.B.; Lima, J.R.; Cunha, J.P,; Agra, M.F. \& Thomas, W.W. 2007. Vegetação e flora no Carirí paraibano. Oecologia Brasiliensis 11: 313-322. 
Eiten, G. 1983. Classificação da vegetação do Brasil. Coordenação editorial do Conselho Nacional de Desenvolvimento Científico e Tecnológico, Brasília. $305 \mathrm{p}$.

Fabricante, J.R \& Andrade, L.A. 2007. Análise estrutural de um remanescente de caatinga no Seridó paraibano. Oecologia Brasiliensis 11: 341-349.

Fernandes, A.G. 1998. Fitogeografia brasileira. Multigraf, Fortaleza. 340p.

Ferraz, E.M.N.; Rodal, M.J.N. \& Sampaio, E.V.S.B. 2003. Physiognomy and structure of vegetation along an altitudinal gradient in the semi-arid region of northeastern Brazil. Phytocoenologia 33: 71-92.

Fonseca, M.R. 1991. Análise da vegetação arbustivoarbórea da caatinga hiperxerófila do noroeste do estado de Sergipe. Tese de Doutorado. Universidade Estadual de Campinas, Campinas. 187p.

Freitas, R.A.C.; Sizenando Filho, F.A.; Maracajá, P.B.; Diniz Filho, E.T. \& Lira, J.F.B. 2007. Estudo florístico e fitossociológico do extrato arbustivoarbóreo de dois ambientes em Messias Targino, divisa RN/PB. Revista Verde 2: 135-147.

Gottschling, M.C \& Miller, J.S. 2006. Clarification of the taxonomic position of Auxemma, Patagonula, and Saccellium (Cordiaceae, Boraginales). Systematic Botany 31: 361-367.

Lemos, J.R. \& Rodal, M.J.N. 2002. Fitossociologia do componente lenhoso de um trecho da vegetação de caatinga no parque nacional da Serra da Capivara, Piauí, Brasil. Acta Botanica Brasilica 16: 23-22.

Luetzelburg, P.V. 1923. Estudo botânico do nordeste. Ministério da viação e obras públicas, Rio de Janeiro. 384p.

Maracajá, P.B.; Batista, C.H.F.; Souza, A.H. \& Vasconcelos, W.E. 2003. Levantamento florístico e fitossociológico na Vila de Santa Catarina, Serra do Mel, RN. Revista de Biologia e Ciências da Terra 3: 1-13.

Moreira, A.R.P.; Maracajá, P.P.; Guerra, A.M.N.M.; Sizenando Filho, F.A. \& Pereira,T.F.C. 2007. Composição florística e análise fitossociológica arbustivo-arbóreo no município de Caraúbas-RN. Revista Verde 2: 113-126.

Nascimento, C.E.S.; Rodal, M.J.N. \& Cavalcanti, A.C. 2003. Phytosociology of the remaining xerophytic woodland associated to an environmental gradient at the banks of the São Francisco River - Petrolina, Pernambuco, Brazil. Revista Brasileira de Botânica 26: 271-287.

Pegado, C.M.A.; Andrade, L.A.; Félix, L.P. \& Pereira, I.M. 2006. Efeitos da invasão biológica de algaroba - Prosopis juliflora (Sw.) DC sobre a composição e a estrutura do estrato arbustivo-arbóreo da caatinga no município de Monteiro, PB, Brasil. Acta Botanica Brasilica 20: 887-898.

Pereira, I.M.; Andrade, L.A.; Barbosa, M.R.V. \& Sampaio, E.V.S.B. 2002. Composição florística e análise fitossociológica do componente arbustivoarbóreo de um remanescente florestal no Agreste Paraibano. Acta Botanica Brasilica 16: 357-2002.

Prado, D.E. 2003. As caatingas da América do Sul. In: Leal, I.R.; Tabarelli, M. \& Silva, J.M.C. (orgs.). Ecologia e conservação da caatinga: uma introdução ao desafio. Imprensa Universitária UFPE, Recife. Pp. 3-74.

Queiroz, J.A.; Trovão, D.M.B.M.; Oliveira, A.B. \& Oliveira, E.C.S. 2006. Análise da estrutura fitossociológica da Serra do Monte, Boqueirão, Paraíba. Revista de Biologia e Ciências da Terra 6: 251-259.

R Development Core Team. 2009. A language and environment for statistical computing. R Foundation for Statistical Computing, Vienna, Austria. Available in $<$ http://www.R-project.org $>$. Access on $23 \mathrm{Feb}$ 2011.

Rizzini, C.T. 1979. Tratado de fitogeografia do Brasil: aspectos sociologicos e floristicos. HUCITEC, São Paulo. 374p.

Rodal, M.J.N.; Martins, F.R. \& Sampaio, E.V.S.B. 2008a. Levantamento quantitativo das plantas lenhosas em trechos de vegetação de caatinga em Pernambuco. Revista Caatinga 21: 192-205.

Rodal, M.J.N.; Costa, K.C.C. \& Silva, A.C.B.L. 2008 b. Estrutura da vegetação caducifólia espinhosa (caatinga) de uma área do sertão central de Pernambuco. Hoehnea 35: 45-53.

Sampaio, E.V.S.B. 1995. Overview of the brazilian caatinga. In: Mooney, H.A.; Bullock, S.H. \& Medina, E. (eds.). Dry tropical forests. Cambridge University Press, Cambridge. Pp. 35-63.

Santana, J.A.S. \& Souto, J.S. 2006. Diversidade e estrutura fitossociológica da caatinga na Estação Ecológica do Seridó - RN. Revista de Biologia e Ciências da Terra 6: 232-242.

Santos, R.M.; Vieira, F.A.; Gusmão, E. \& Nunes, Y.R.F. 2007. Florística e estrutura de uma floresta estacional decidual, no Parque Municipal da Sapucaia, Montes Claros (MG). Cerne 13: 248256.

Shepherd, G.J. 1995. FITOPAC 1. Manual do usuário. Universidade Estadual de Campinas, Campinas.

Veloso, H.P.; Rangel-Filho, A.L.R. \& Lima, J.C.A. 1991. Classificação da vegetação brasileira, adaptada a um sistema universal. IBGE, Rio de Janeiro. 124p. 